\title{
Collembola populations under sclerophyllous coppices in Provence (France): comparison between two types of vegetation, Quercus ilex L. and Quercus coccifera $\mathrm{L}$.
}

\author{
Jérôme Cortet *, Nicole Poinsot-Balaguer \\ * Corresponding author jerome.cortet@univ-montp3.fr)
}

\begin{abstract}
A comparative analysis of soil Collembola using two types of sclerophyllous vegetation (Quercus ilex and Quercus coccifera) was performed at a calcareous site in Provence (France). Collembola populations were examined over a one-year period (11 successive months) in three different soil layers. Although no statistically significant differences could be observed for Collembola abundance and diversity, multivariate analyses (FCA) differentiated the two coppices. Phenologies of some species showed specific responses to the microclimate induced by edaphic conditions. Even though the two coppices were sclerophyllous, the structure of each vegetation, the quantity and quality of litter, which were different, could influence environmental conditions and thus the dynamics of collembolan populations.
\end{abstract}

Collembola / phenology / Quercus ilex / Quercus coccifera / litter decomposition

\section{INTRODUCTION}

Dynamics of microarthropods in the Mediterranean area are strongly linked to climate. In summer, soil arthropods are subjected to a severe selection process due to drought, which causes a typical response in population structure: two population peaks, one in spring and the other in autumn, with a minimum in summer. Although most mesofauna are generally cosmopolitan in nature, several original features can be observed in the Mediterranean area. In winter, species richness is high, along with population densities, and the three most important groups of microarthropods (Collembola, Oribatei and Prostigmata) are about equal in abundance, as is generally observed in temperate climates [21]. In summertime, as generally observed in desert climates, densities decrease; the number of taxa is reduced but mites remain dominant [7]. Typically, Collembola cannot survive drought, and only some species of Acari remain $[8,23]$.

The type of vegetation plays an important role in soil formation, especially in Mediterranean areas: each type of tree produces a litter with a specific quality and quantity. Substrate quality has a great influence on remaining litter mass in sclerophyllous vegetations [9], and consequently influences the structure and the dynamics of edaphic populations. A previous comparison between the mesofauna of an evergreen oak litter and a white oak litter in a forest of the Provençal region (France), has shown that in the $\mathrm{H}$ layer, there was no difference, whereas in the underlying layer, there was a significant difference [23]. The three main groups of microarthropods showed different responses to the vegetation cover: oribatids preferred the green oak forests, whereas Collembola and other mites preferred the white oak forest. It is known that evergreen oak leaves have a high content of tannins, which is a repulsive substance for Collembola [24].

Our research attempts to demonstrate the influence of litter quantity and quality of Quercus ilex and Quercus coccifera, which are typical Mediterranean sclerophyllous coppice woods, and vegetation cover, on the structure and the dynamics of Collembola populations, strictly under the same climate and topographic conditions.

\section{MATERIALS AND METHODS}

\subsection{Study site}

This study was performed on the Petit Arbois plateau in the department of the Bouches du Rhône near the village of Calas, $25 \mathrm{~km}$ from Marseilles at an ele- 
vation of $150 \mathrm{~m}$ above sea level. This site has a typical Mediterranean climate, with two months of maximum rainfall during the study year: October $(147.2 \mathrm{~mm})$ and April $(112.4 \mathrm{~mm})$, and a minimum in June $(0.2 \mathrm{~mm})$.

The landscape is made up of a calcareous bedrock. Soil is often absent; thus, large patches of limestone appear with only sparse vegetation: only xerophilous plants, such as Thymus vulgaris, Euphorbia spinosa, Asparagus acutifolius and Brachypodium restusum can grow there. Some outcroppings with a thicker brown calcareous soil can be observed, making it possible for Quercus ilex or Q. coccifera to grow, which then form small single coppices.

Two stations, located about only $10 \mathrm{~m}$ from each other to reduce microclimatic and topographic variations, were selected for this study. Slope was insignificant. Three layers of litter were defined [17]: the L layer, which included recently fallen leaves only slightly decomposed; the F layer, which included well decomposed leaves; and the $\mathrm{H}$ layer, comprised of humus derived from decomposed litter mixed with the soil. The xeromorph characteristics of the sclerophyllous oak leaves contribute to the formation of a xeromoder on calcareous bedrock [6].

In station 1, vegetation was represented by Quercus ilex, which covered the whole soil. Here, a high amount of L layer could be found (3-4 cm of depth). The $\mathrm{F}$ layer had a depth of 2 to $3 \mathrm{~cm}$. The $\mathrm{H}$ layer had a depth of 4 to $5 \mathrm{~cm}$.

At station 2, Quercus coccifera was dominant. The L layer was less thick (only 1 or $2 \mathrm{~cm}$ ) than at station 1. The $F$ layer had a depth of 2 to $3 \mathrm{~cm}$, and the $\mathrm{H}$ layer was 4 to $5 \mathrm{~cm}$ deep.

\subsection{Field methods}

In each vegetation type, on a surface area of about $25 \mathrm{~m}^{2}$, samples were taken every month from October 1994 to August 1995: one from the L layer, one from the $\mathrm{F}$ layer and another from the $\mathrm{H}$ layer. This operation was repeated four times, at a distance of one meter from each other. Thus, a total of 264 samples were taken, divided over 3 layers, 4 replicates, 2 stations and 11 months.

Although seasonal variations in quantity of litter fall appeared [15], volume of samples $\left(500 \mathrm{~cm}^{3}\right)$ and surface of sampling $\left(400 \mathrm{~cm}^{2}\right)$ were the same during all the study.

Decomposition of Quercus ilex and $Q$. coccifera leaves was studied using $100 \mathrm{~cm}^{2}$ litter bags of $2-\mathrm{mm}$ mesh size. Oak leaves were collected from the study sites, dried at $45^{\circ} \mathrm{C}$ for $24 \mathrm{~h}$, weighed to $5 \mathrm{~g}$, then placed in bags.

On 18 November 1994, 20 litter bags were laid on the soil surface at the two selected stations of Quercus ilex and $Q$. coccifera coppices. The two litter bags were collected from each site, at different dates for seven months, from January to July 1995.

\subsection{Analytical and laboratory methods}

Soil cores were placed in a Berlese-Tullgren apparatus to extract soil fauna: animals were collected in vials containing $60 \%$ alcohol solution. Collembola were counted under a binocular microscope and identified to the species level [10]. Litter bags were brushed clean of leaves and detritus and washed in running water to remove any remaining soil particles clinging to them. Then, the samples were oven dried $\left(45^{\circ} \mathrm{C}\right.$ for $\left.24 \mathrm{~h}\right)$ and weighed.

\subsection{Statistical methods}

Diversity was evaluated using the index of Shannon:

$$
I s h=-\frac{n i^{2}}{N} \log \left(\frac{n i}{N}\right)
$$

where $n i$ is the number of individuals of species $i$ and $N$, total number of individuals.

Differences between densities and species diversity of the two vegetation types were tested using the Mann-Whitney test.

A FCA (factorial correspondence analysis) [3, 4] was applied to the Collembola population data [25]. Twenty-seven variables were used, which corresponded to species found in the two types of coppices. For each month and each depth, the sum of all four samples was taken. Thus, 66 items were studied (33 for each vegetation type). Densities were divided into seven classes, based on the number of individuals in four samples:

1: no individuals;

2: 1 to 5 individuals;

3: 6 to 10 individuals;

4: 11 to 20 individuals;

5: 21 to 50 individuals;

6: 51 to 100 individuals;

7: more than 100 individuals.

This classification implies a loss of information because the original densities are no longer used. However, it decreases the weight of some data whose values are disproportionate, which makes interpretation easier [5].

All statistics concerning Collembola were obtained using the STATITCF program on an IBM computer.

Differences between leaves decomposition were studied using the ANOVA, with the STATVIEW program on an IBM computer. 


\section{RESULTS}

\subsection{Collembola abundance}

The maximum density of Collembola (mean number of individuals $\cdot \mathrm{dm}^{-3}$ ) was observed in the $\mathrm{F}$ layer in the two coppice types, but the location of the minimum varied. Mean number was always higher under Quercus coccifera than Quercus ilex, but no significant differences between the two coppice population densities were found (table I).

Table I. Comparison of Collembola populations (mean density $\cdot \mathrm{dm}^{-3}$ ) in the three studied layers $(\mathrm{L}, \mathrm{F}, \mathrm{H})$ under Quercus ilex and $Q$. cocci. fera coppices, over the complete sampling period.

\begin{tabular}{cccc}
\hline Layer & $\begin{array}{c}\text { Quercus } \\
\text { ilex }\end{array}$ & $\begin{array}{c}\text { Quercus } \\
\text { coccifera }\end{array}$ & Difference \\
\hline L & 109 & 157 & n.s. \\
F & 379 & 471 & n.s. \\
H & 117 & 150 & n.s. \\
\hline
\end{tabular}

n.s., non significant

Collembola showed very different seasonal pattems under the two forms of vegetation, especially in the $\mathrm{F}$ and $\mathrm{H}$ layers; they reached a high abundance in June or July under Quercus ilex, but were more abundant in January and February under Quercus coccifera. In the L layer, peaks of density were more pronounced under Quercus coccifera during the wet season, but less pronounced than under Quercus ilex in July (figure 1).

\subsection{Collembola diversity}

Twenty-seven species were collected (table II). Poinsot-Balaguer [20] had found 34 species on the same site. Most of these species are known to have a wide distribution; only one is typically Mediterranean: Capraiena echinata (table II).

Species diversity under Quercus ilex seemed to be relatively stable and high in the three layers, from October to May. Then, a decrease was observed, with a minimal diversity in June for the $\mathrm{H}$ layer, in July for the F layer and in August for the L layer. The decrease was less pronounced in the deepest layers (figure 2A).

In the L layer of Quercus coccifera litter, a high diversity was observed in November and April, and a low diversity during August, as is usually observed in Mediterranean areas. In the two deeper layers, two peaks were observed in December and March, but no decrease was found in summer, rather the highest diversities were found during July in the $\mathrm{H}$ layer and May in the F layer (figure 2B).

Standard deviations and variances of Shannon indices over the eleven months, illustrated the influ-
Table II. List of Collembola species found under Quercus ilex and Q. coccifera coppices.

\begin{tabular}{|c|c|}
\hline Species & Abbreviations used \\
\hline Tomocerus baudoti (Denis) & Tbau \\
\hline Heteromurus major (Moniez) & Hmaj \\
\hline Lepidocyrtus cyaneus (Tullberg) & Lcya \\
\hline Orchesella quinquefasciata (Bourlet) & Oqui \\
\hline Pseudosinella alba (Packard) & Palb \\
\hline Seira dolfusi (Carl) & Sdol \\
\hline Isotoma notabilis (Schäffer) & lnot \\
\hline Isotomiella minor (Schäffer) & Imin \\
\hline Isotoma viridis (Bourlet) & lvir \\
\hline Isotomurus maculatus (Mûller) & Imac \\
\hline Xenylla maritima (Tullberg) & Xmar \\
\hline Hypogastrura tullbergi (Schäffer) & Htul \\
\hline Hypogastrura armata (Nicolet) & Harm \\
\hline Brachystomella parvula (Schäffer) & Bpar \\
\hline Bilobella aurentiaca (Caroli) & Baur \\
\hline Neanura muscorum (Templeton) & Nmus \\
\hline Anurida pygmaea (Bôrner) & Apyg \\
\hline Megalothorax minimus (Willem) & Mmin \\
\hline Megalothorax murinus (Folsom) & Mmur \\
\hline Sminthurinus aureus (Lubbock) & Saur \\
\hline Sminthurinus denisi (Cassagnau) & Sden \\
\hline Sminthurus fuscus (Linné) & Sfus \\
\hline Sminthurus elegans (Cassagnau) & Sele \\
\hline Caprainea echinata (Stach) & Cech \\
\hline Sphaeridia pumilis (Krausbauer) & Spum \\
\hline Tullbergia krausbaueri (Lubbock) & Tkra \\
\hline Onychiurus gr: armatus (Gervais) & Oarm \\
\hline
\end{tabular}

ence of depth on Collembola community structure under Quercus ilex coppices: a greater variability in diversity was observed in the L layer than in the deeper layers (table III).

Responses under $Q$. coccifera coppices were not so pronounced: a clear gradient in standard deviations or variances could not be observed. Under both types of vegetation, however, diversity increased with depth. The mean Shannon indices were slightly higher, but not significantly, under Quercus ilex than $Q$. coccifera for the three studied layers (table III).

\subsection{Collembola phenology}

In both sampling sites, phenologies were studied for all species. Six species were selected for detailed analysis, although each species had his own phenology:

- Isotoma notabilis and Xenylla maritima because they were the most abundant; 
- Sphaeridia pumilis for its particular phenology:

- Hypogastrura armata and Hypogastrura tullbergi. which belong to the same genus. but had different behaviours:

- Heteromurus major because it is a common epigeal species.

Xenylla maritima populations increased rapidly during summer, from May to July, and contributed largely to the peak observed at this time for Collembola; in July, it represented $83 \%$ of total Collembola (figure 3). This explosion of Xenylla maritima populations explains the fall of diversity, observed in summer, particularly in the $\mathrm{L}$ and $\mathrm{F}$ layers. Hypogastrura armata had only one short peak in December (figure 3). Hypogastrura tullbergi showed two peaks. in January and March, under both coppices, but while the highest peak was in January under Quercus coc-

\section{L layer}

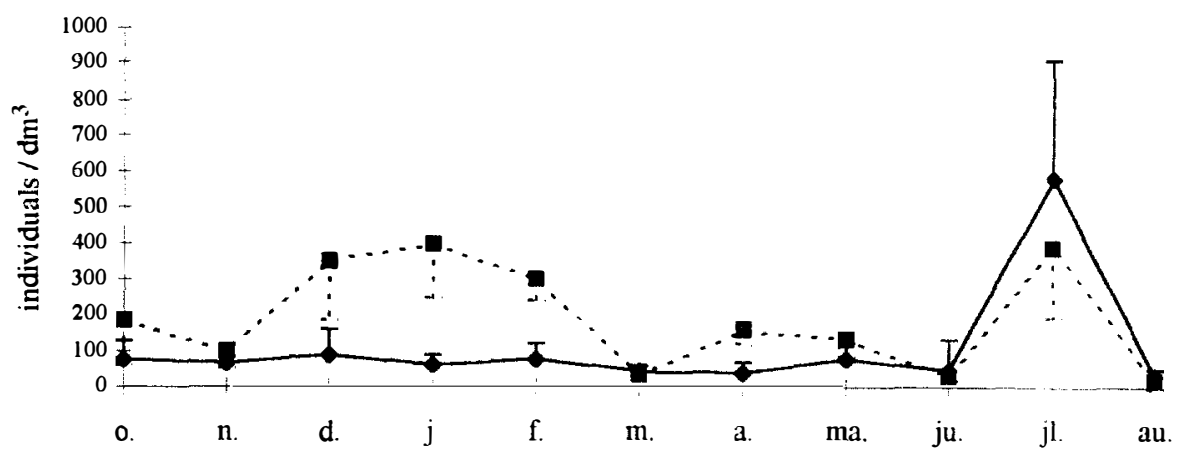

\section{F layer}

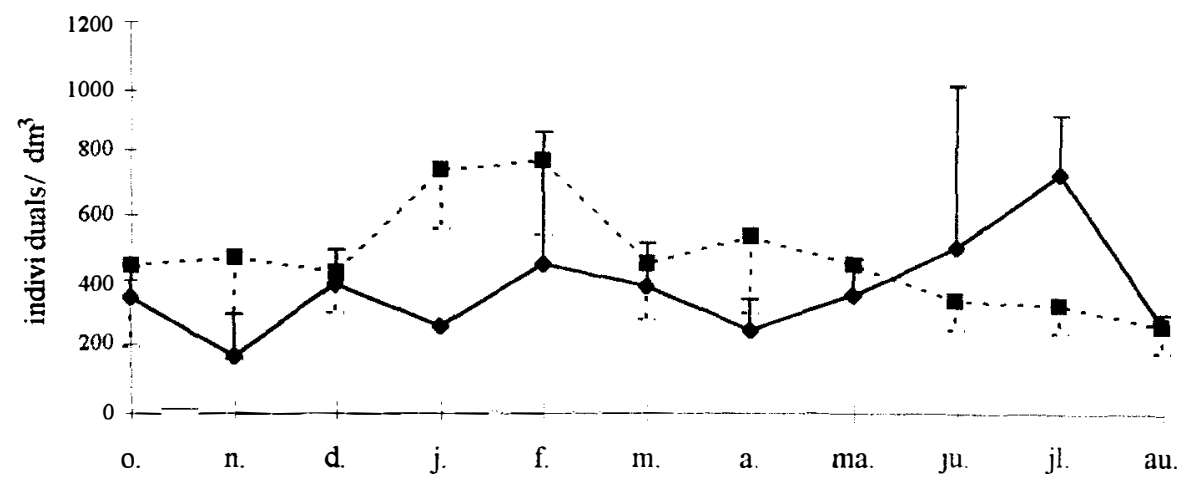

Figure 1. Monthly densities of Collembola under Quercus ilex (solid lines) and Quercus coccifera (broken lines) in the three studied layers (L. F, H).

\section{H layer}

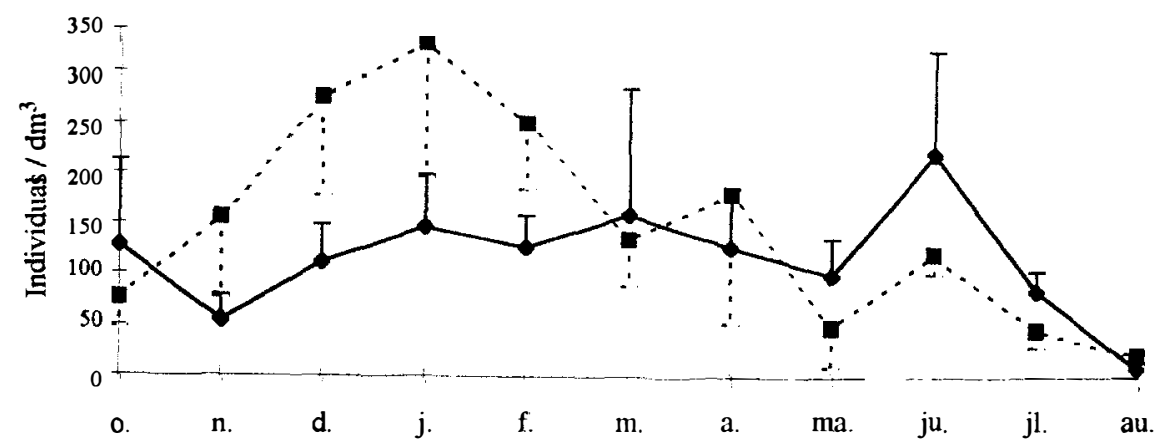



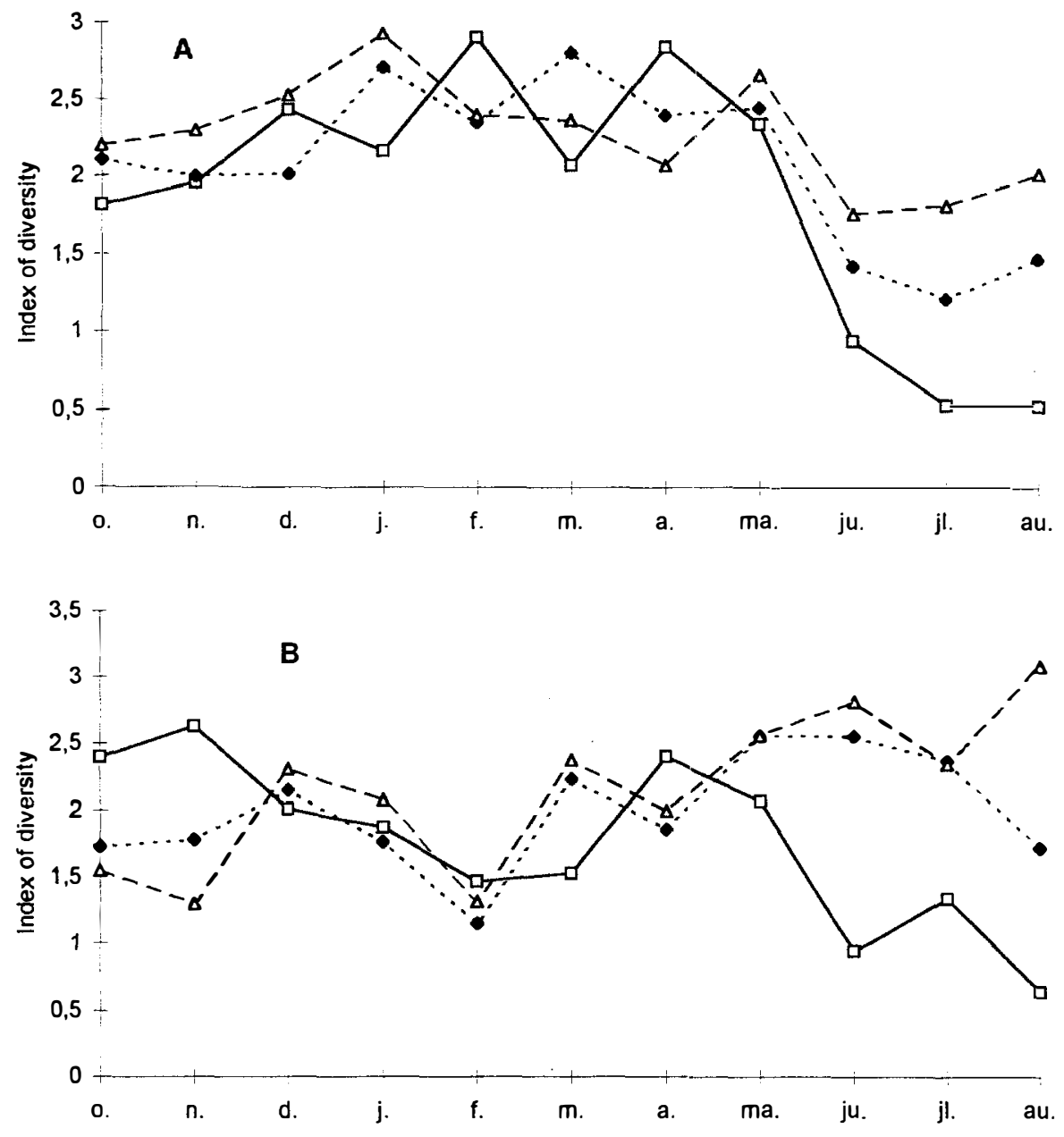

Figure 2. Monthly diversity of Collembola under Quercus ilex (A) and $Q$. coccifera $(\mathrm{B})$ in the three studied layers (L: - ---. F: $\left.\mathrm{H}:-\Delta^{--}\right)$ cifera, it occurred in March under Quercus ilex. Isotoma notabilis had a wide distribution over the year, with high densities from October to May (figure 3).

Differences between the two coppices occurred for all species, but they were very pronounced for some of them: differences were significant for Sphaeridia pumilis under Quercus coccifera coppices with peaks in October, April and July; the inverse reaction was observed for Heteromurus major, whose densities were higher under Quercus ilex vegetation, from December to August (figure 3).

\subsection{Factorial correspondence analysis}

The first three axes represented $44.6 \%$ of the total variation. This low percentage is common and must not be considered as an obstacle to the interpretation of ecological data [3].

Table III. Mean Collembola diversity (Shannon index expressed in bits) in the three studied layers (L, F. H) under Quercus ilex and Q. coccifera coppices over the complete sampling period.

\begin{tabular}{ccccc}
\hline \multirow{2}{*}{ Layer } & \multicolumn{2}{c}{ Quercus ilex } & & \multicolumn{2}{c}{ Quercus coccifera } \\
\cline { 2 - 3 } \cline { 5 - 6 } & Diversity & Standard deviation & & Diversity \\
\hline L & 1.86 & 0.84 & 1.75 & 0.63 \\
$\mathrm{~F}$ & 2.08 & 0.53 & 1.99 & 0.42 \\
$\mathrm{H}$ & 2.27 & 0.35 & 2.15 & 0.58 \\
\hline
\end{tabular}



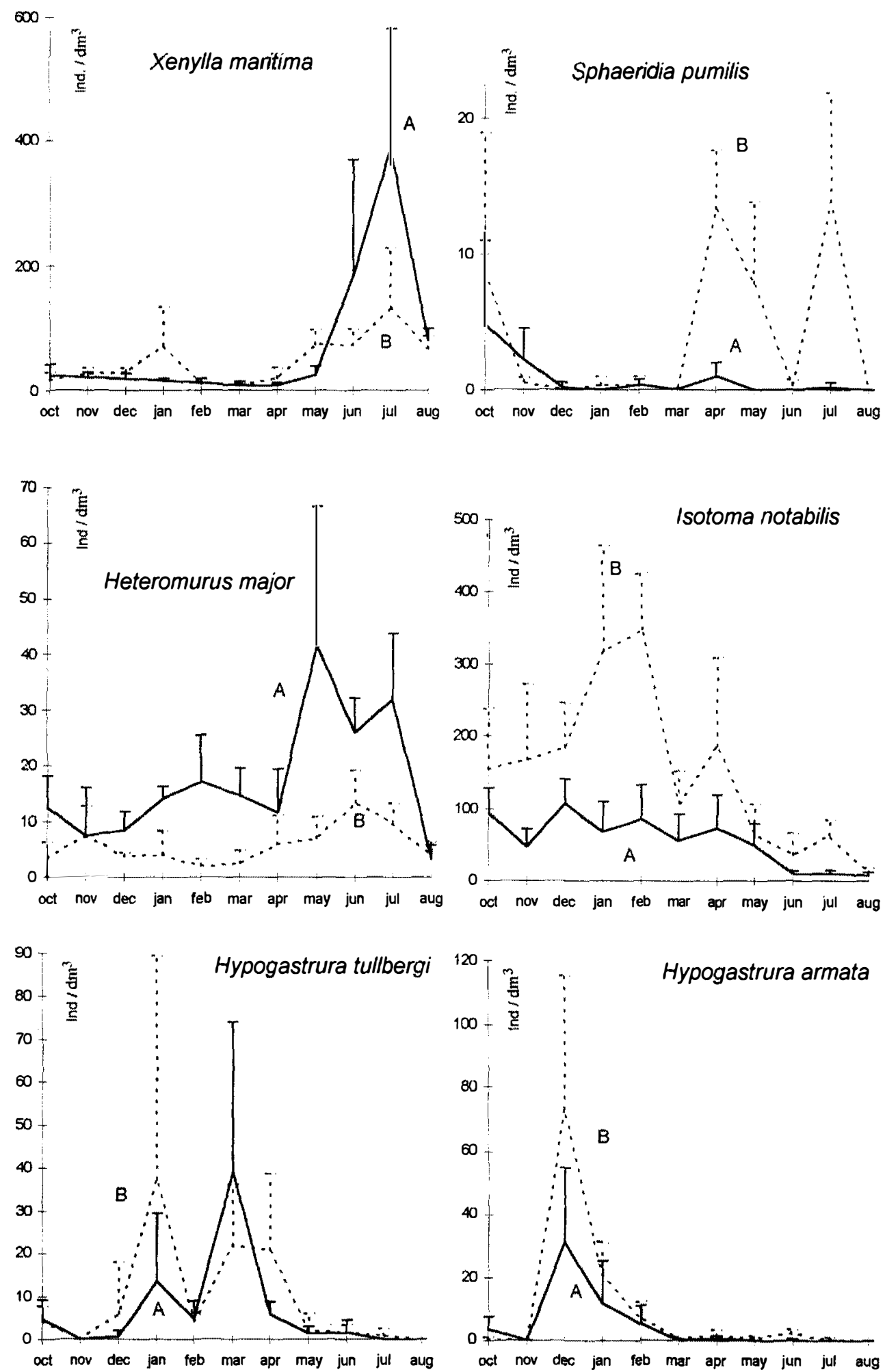

Figure 3. Monthly densities of six species of Collembola under Quercus ilex (A) and Q. coccifera (B) coppices. For each month, the mean is shown with its standard deviation. 
The first axis represented $19.2 \%$ of the variation. Analysis of relative contributions to this axis shows a clear distinction between samples taken during the cold season (particularly December and February) and those taken during the hot season (July, June and May). Axis 1 of the FCA thus illustrates the influence of temperature (table IV). Furthermore, while Lepi. docyrtus cyaneus, Heteromurus major and Orchesella quinquefasciata were strongly correlated with the hot season, other species such as Hypogastrura armata, Megalothorax minimus and $M$. murinus were particularly present in winter (table IV).

The second axis was more difficult to interpret and seemed to contrast autumn (October and November) with March and January (table V). Some species tended to be particularly dominant in autumn: Sminthurinus aureus, Tomocerus baudoti and Megalothorax minimus; others preferred March and January: Hypogastrura tullbergi, Tullbergia krausbaueri and Megalothorax minimus (table V).

A graph of the loadings to the first two axes of the FCA (figure 4A and B) illustrates the seasonal cycle. Figure 4A shows that the samples are mainly sorted with respect to time and succeed each other in a counterclockwise manner. Figure 4B shows that Megalothorax minimus was particularly present in spring and summer, Megalothorax murinus preferred summer and autumn.

Table IV. List of the most important relative contributions to the inertia explained by axis 1 of the factorial correspondence analysis.

\begin{tabular}{|c|c|c|c|c|}
\hline & \multicolumn{2}{|c|}{$\begin{array}{l}\text { Contributions of samples } \\
\text { ( } 1 \text { sample }=1 \text { date associated with } 1 \text { station) }\end{array}$} & \multicolumn{2}{|c|}{$\begin{array}{c}\text { Contributions of variables } \\
\text { ( } 1 \text { variable }=1 \text { Collembola species })\end{array}$} \\
\hline & December $(Q$. cocc. $)$ & 9.3 & H. armata & 11.1 \\
\hline & December $(Q$. cocc. $)$ & 7.9 & M. minimus & 8.2 \\
\hline \multirow[t]{6}{*}{ Negative } & December $(Q . c o c c)$. & 6.1 & M. murinus & 7.3 \\
\hline & December $(Q$. ilex $)$ & 3.4 & & \\
\hline & December $(Q$. ilex $)$ & 2.9 & & \\
\hline & February $(Q$. cocc. $)$ & 2 & & \\
\hline & July $(Q$. ilex $)$ & 5.5 & L. cyaneus & 23.8 \\
\hline & June $(Q$. cocc. $)$ & 4.7 & H. major & 12.3 \\
\hline \multirow[t]{4}{*}{ Positive } & July (Q. ilex) & 3.9 & O. quinquefasciata & 5.9 \\
\hline & May $(Q . \operatorname{cocc})$. & 3.7 & & \\
\hline & July $(Q \cdot \operatorname{coc} c)$ & 3.3 & & \\
\hline & April (Q. ilex) & 2.6 & & \\
\hline
\end{tabular}

Table V. List of the most important relative contributions to the inertia explained by axis 2 of the factorial correspondence analysis.

\begin{tabular}{|c|c|c|c|c|}
\hline & \multicolumn{2}{|c|}{$\begin{array}{l}\text { Contributions of samples } \\
\text { ( } 1 \text { sample }=1 \text { date associated with } 1 \text { station) }\end{array}$} & \multicolumn{2}{|c|}{$\begin{array}{c}\text { Contributions of variables } \\
\text { ( } 1 \text { variable }=1 \text { Collembola species })\end{array}$} \\
\hline & $\operatorname{March}(Q . \operatorname{cocc})$. & 5.8 & H. tullbergi & 21.8 \\
\hline & $\operatorname{March}(Q$. ilex $)$ & 4.1 & T. krausbaueri & 9.9 \\
\hline \multirow[t]{6}{*}{ Negative } & March (Q. ilex) & 3.1 & M. minimus & 3.4 \\
\hline & January $(Q . \operatorname{cocc})$. & 2.9 & & \\
\hline & January $(Q . \operatorname{cocc})$. & 2.7 & & \\
\hline & February $(Q$. ilex $)$ & 2.6 & & \\
\hline & November (Q. cocc.) & 14.9 & S. aureus & 10.7 \\
\hline & October $(Q . c o c c)$. & 7 & T. baudoti & 10.4 \\
\hline \multirow[t]{4}{*}{ Positive } & November (Q. ilex) & 5.1 & M. murinus & 6.8 \\
\hline & October $(Q . \operatorname{cocc})$. & 4.2 & & \\
\hline & November $(Q$. cocc. $)$ & 3.3 & & \\
\hline & November (Q. cocc.) & 3.2 & & \\
\hline
\end{tabular}



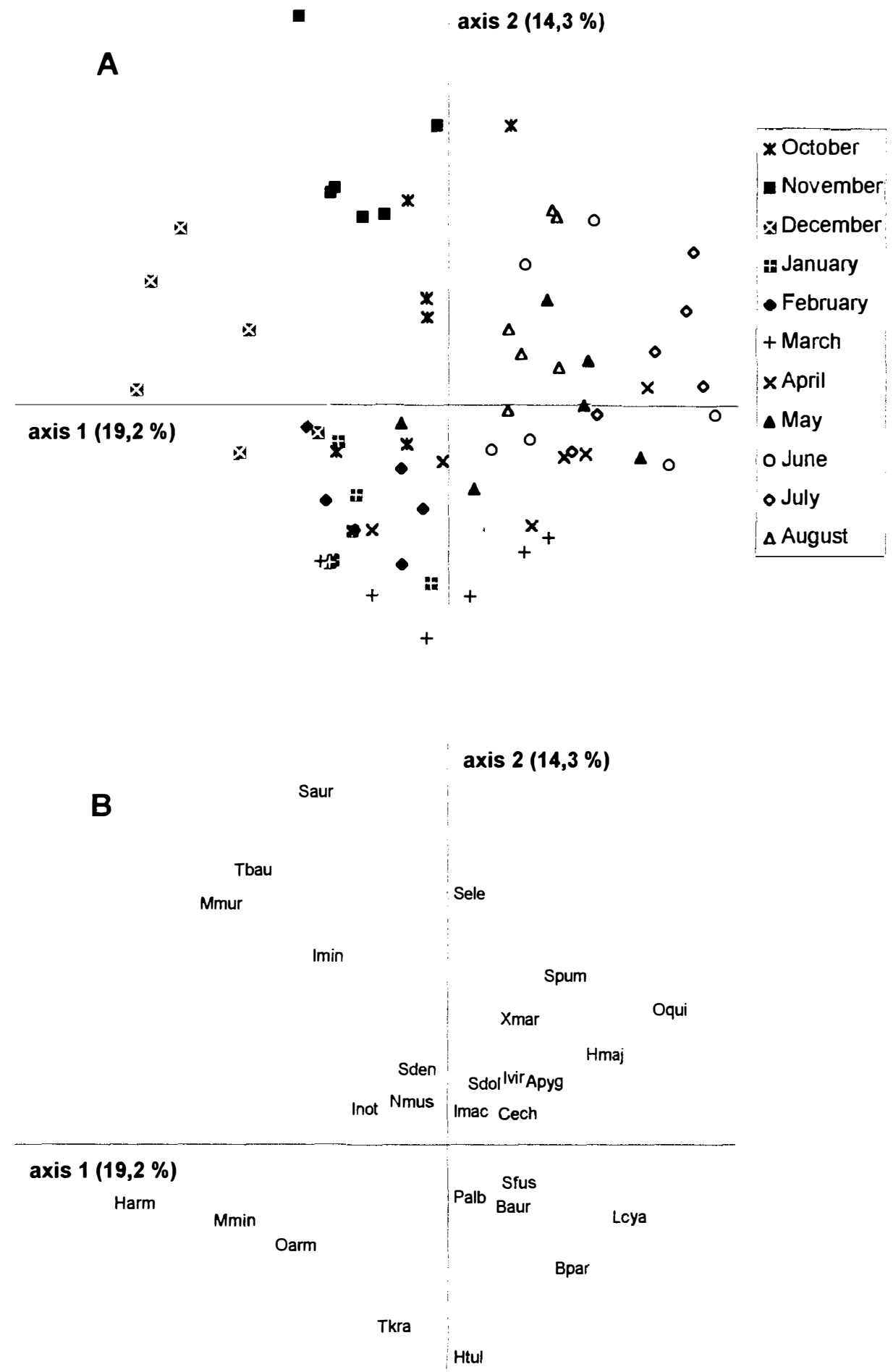

Figure 4. First map of the factorial correspondence analysis: axis I and 2 (samples (A) and variables (B) are represented separatly). For species codes see table II. 


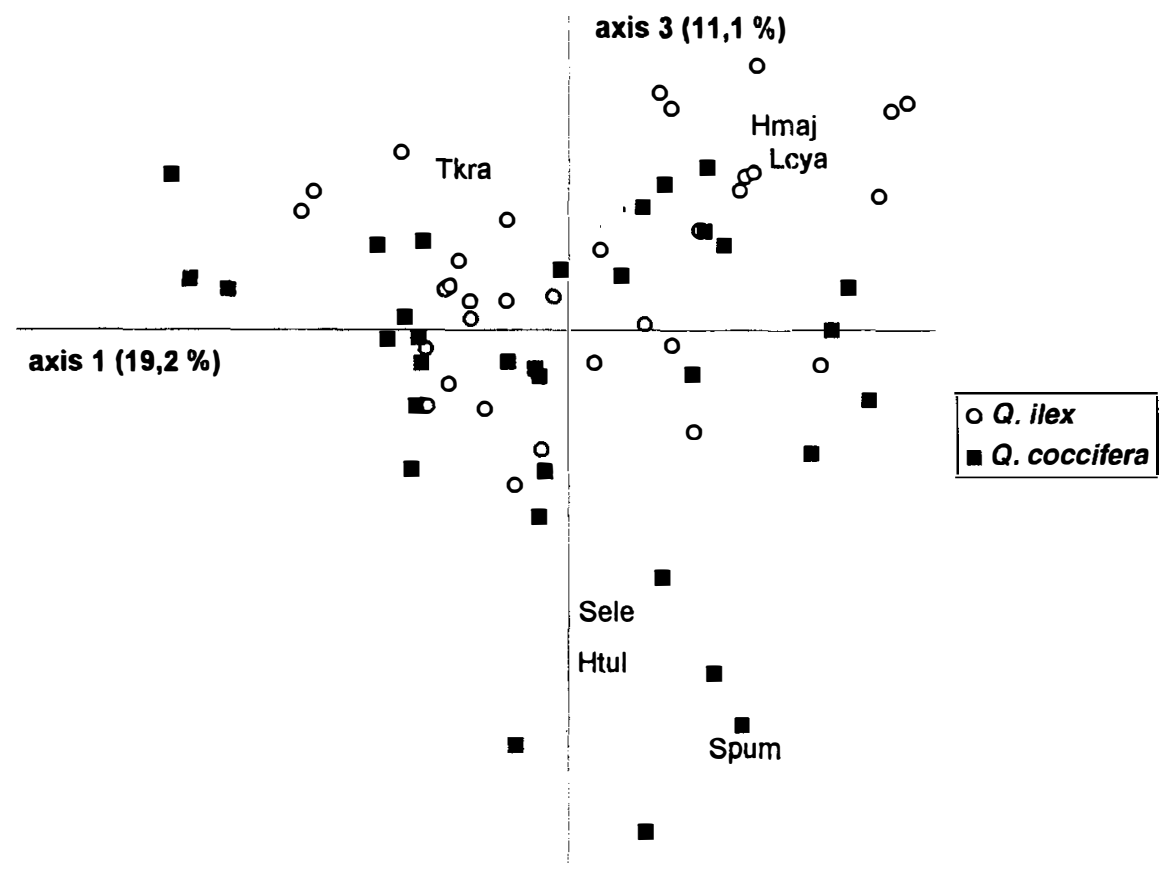

Figure 5. Second map of the factorial correspondence analysis: axis 1 and 3 . For species codes see table II.

The third axis was very interesting, because it seemed to oppose Quercus ilex coppices, represented by species such as Lepidocyrtus cyane us, Heteromurus major or Tullbergia krausbaueri, to Quercus coccifera formations, represented by species such as Hypogastrura tullbergi, Sphaeridia pumilis or Sminthurinus elegans. This axis represented $11.1 \%$ of the variation (table VI and figure 5). Furthermore, Quercus coccifera coppice seems to be well characterised by sam- ples extracted during the wet season, whereas Quercus ilex coppice seems to be well characterised by summer samples. The large amount of variation remaining in the FCA $(55.4 \%)$ should be attributed to other parameters such as vertical distribution. Furthermore, the big standard errors, observed between samples, show the importance of sampling errors due to aggregation behaviour, which is influenced by microhabitat variations (figure 3).

Table VI. List of the more important relative contributions to the inertia explained by axis 3 of the factorial correspondence analysis.

\begin{tabular}{|c|c|c|c|c|}
\hline & \multicolumn{2}{|c|}{$\begin{array}{c}\text { Contributions of samples } \\
\text { (1 sample }=1 \text { date associated with } 1 \text { station) }\end{array}$} & \multicolumn{2}{|c|}{$\begin{array}{c}\text { Contributions of variables } \\
\text { ( } 1 \text { variable }=1 \text { Collembola species })\end{array}$} \\
\hline & Q. coccifera (October) & 17.4 & S. pumilis & 28.2 \\
\hline & Q. coccifera (October) & 13.4 & H. tullbergi & 24.4 \\
\hline \multirow[t]{6}{*}{ Negative } & Q. coccifera (April) & 10.4 & S. elegans & 8.5 \\
\hline & Q. coccifera (April) & 9.3 & & \\
\hline & Q. coccifera (March) & 2.6 & & \\
\hline & Q. coccifera (October) & 1.8 & & \\
\hline & Q. ilex (July) & 14.9 & L. cyaneus & 7 \\
\hline & Q. ilex (August) & 7 & H. major & 6.6 \\
\hline \multirow[t]{4}{*}{ Positive } & Q. ilex (June) & 5.1 & T. krausbaueri & 4.5 \\
\hline & Q. ilex (July) & 4.2 & & \\
\hline & Q. ilex (June) & 3.3 & & \\
\hline & Q. ilex (December) & 3.2 & & \\
\hline
\end{tabular}




\subsection{Leaf decomposition}

After 234 days, results show a lower decomposition under Quercus ilex than Q. coccifera coppices: $25.2 \%$ of Quercus coccifera litter mass had disappeared, but only $16.3 \%$ under Quercus ilex. Furthermore, a significant difference appeared between the two litter types, during the decomposition process (ANOVA on litter mass loss data, with the factor 'type of litter').

The interaction between time and type of litter (table VII) was not significant, which suggests that the two litter types lose mass in a similar way.

Thus, the dynamics of leaf decomposition seems to follow the same pattern under the two coppices, but during the initial phases, litter-mass loss is faster for Quercus coccifera.

Table VII. Results of the ANOVA on litter mass loss data, with 3 different factors (type of litter: Quercus ilex and Quercus coccifera; date: seven months for each type of litter; date*type of litter: interactions between the 2 factors). The table gives the $P$ values for each F-test.

\begin{tabular}{lccc}
\hline $\begin{array}{l}\text { Source of variation } \\
\text { of litter }\end{array}$ & $\begin{array}{c}\text { Type } \\
\text { Difference } \\
\text { (litter mass loss data) }\end{array}$ & $\begin{array}{c}\text { Date*type } \\
\text { of litter }\end{array}$ \\
\hline
\end{tabular}

n.s., non significant.

\section{DISCUSSION}

In the litter and soil of the two studied coppices, the responses obtained, corresponded more or less with those previously observed in French Mediterranean regions [20, 23]: climatic factors (essentially drought in summer) play a key role in the structure and dynamics of edaphic microarthropod populations, and Collembola populations showed the typical structure and dynamics of the Mediterranean area, with minimum fauna in summer. It has already been observed that diversity fluctuates with seasons. The minimum is always found in summer; diversity begins to decrease in the L layer during spring.

Like the other groups of microfauna, Collembola are more abundant in the F layer, where climatic variations are less pronounced than in the L layer [19]. Although we did not study vertical distribution in this paper, we realised that Collembola often accomplish significant vertical migrations to avoid drought stress in the L layer [22].

A succession of Collembola species was observed over a seasonal cycle in Greece by Sgardelis et al. [27]. They observed an increase in mortality during the dry season and a succession of different species during the wet period in an evergreen formation. Under Quercus coccifera coppices, also in Greece, Argyropoulou et al. [2] concluded that an annual periodicity exists with rapid fluctuations before, during and after summer. In the same ecosystem, Stamou et al. [28] studied phenologies of different populations of microarthropods and concluded that a specific annual periodicity existed for each species. For example, while Sphaeridia pumilis was particularly present in spring and in autumn, Xenylla maritima populations increased rapidly during the summer. These results seem to agree with ours. Indeed, we observed a rapid expansion of Xenylla maritima in July, and we demonstrated that some species have a similar phenology in the two litters. with only small differences.

Concerning the influence of climatic conditions, the thickness of litter could also be of great importance, especially in the Mediterranean area. A thicker litter will maintain a higher soil moisture content during the dry season and influence densities and/or diversities of microarthropods [19].

It is well known that productivity of litter is higher under Quercus ilex than under $Q$. coccifera coppices [15]. However, a thick litter could reflect a slower decomposition of leaves by microorganisms, which make large contributions to microarthropods diets: in this case, the litter quantity would be a consequence of the litter quality.

Gallardo and Merino [9], based on previous studies [18], differentiated two phases during litter decomposition: a leaching phase of soluble carbohydrates and low molecular tannins, that lasted 2-4 months and a post-leaching phase (aromatic compounds). Our results show that decomposition of Quercus coccifera leaves is faster during the first phases of degradation. Indeed, the percentage of soluble substances should be higher in these leaves, whereas Quercus ilex leaves would contain more aromatic compounds.

Other studies could confirm differences between the two types of leaves: under laboratory conditions, Rapp [26] found higher litter decomposition for Quercus coccifera (42\% of mass loss) than for Q. ilex (37.2\%) over thirty-two weeks. Recently, Ibrahima et al. [13] observed different results for initial properties between Quercus ilex and $Q$. coccifera leaves: lignin/nitrogen and $\mathrm{C} / \mathrm{N}$ ratios were lower in Quercus coccifera than $Q$. ilex leaves. These ratios seem to have a great influence on litter decomposition during the post-leaching phase which is more influenced by biological factors than the leaching phase.

Various studies have tried to correlate environmental factors, especially plant communities and soil chemistry to Collembola populations. Results show great differences between studies. Hågvar [11], in Norwegian coniferous forests soils under similar climatic 
conditions, found differences between Collembola populations in sites covered by different plant communities: soil fertility strongly related with plant community seemed to have a great influence on total abundance, species diversity and species number. However, it was difficult to link particular Collembola species with soil chemistry, whereas $\mathrm{pH}$, basic saturation, $\mathrm{Ca}, \mathrm{Mg}$ and $\mathrm{Mn}$ seemed to increase with soil fertility [12]. In Egypt, Al-Assiuty et al. [1] compared microarthropod communities of different localities and vegetation types: for Collembola, significant differences were found between sites, but no differences could be observed between banana and orange plantations at the same site.

Some differences were observed between Collembola populations living under heterogeneous sclerophyllous coppices. Majer and Greenslade [16] discovered specific differences in Collembola communities under Quercus ilex and its associated maquis. Legakis [14] suggested that there are not four different communities (canopy, litter, stone and soil) but only one, corresponding to the dominant plant species. Poinsot-Balaguer and Tabone [23] observed significant differences between two Quercus ilex Collembola populations: the first living in accumulated organic matter settled at the bottom of a slope, and the second situated in a dryer station with leaching of organic matter. The multivariate analysis of our study showed clear differences in collembolan populations between Quercus ilex and $Q$. coccifera, and tend to confirm the influence of the edaphic context. Thus, in the same climatic environment, some species can show particular adaptations, in relationship with local microclimatic or edaphic conditions. This is the case for both Sphaeridia pumilis and Heteromurus major.

It seems that the two most important factors (climate and leaf quality), which could affect Collembola populations, do not have the same influence in every season. In summer climatic stress is predominant. Thus, thickness of litter, which is higher under Quercus ilex than $Q$. coccifera, could explain the higher densities of Collembola in summer under Quercus ilex coppices. However, during the wet season, litter quality could have a higher influence. Indeed, Collembola densities are higher under Quercus coccifera coppices, whose litter quality could be less repulsive for Collembola than Quercus ilex litter [24].

\section{Acknowledgements}

We wish to thank Gilles Bonin for his help during the statistical calculations.

\section{REFERENCES}

[1] Al-Assiuty A.I.M., Bayoumi B.M., Khalil M.A., Van Straalen N.M., The influence of vegetational type on seasonal abundance and species composition of soil fauna at different localities in Egypt, Pedobiologia 37 (1993) 210-222.

[2] Argyropoulou M.D., Asikidis M.D., Iatrou G.D., Stamou G.P., Colonisation patterns of decomposing litter in a maquis ecosystem, Eur. J. Soil Biol. 29 (1993) 183-191.

[3] Benzecri J.P., L'analyse des données, 1:2: l'Analyse des Correspondances, Dunod, Paris, 1973, 619 p.

[4] Benzecri J.P., Benzecri F., Pratique de l'analyse des données, 1 : Analyse des correspondances, exposé élémentaire, Dunod, Paris, 1980, $425 \mathrm{p}$.

[5] Bonin G., Tatoni T., Réflexions sur l'apport de l'analyse factorielle des correspondances dans l'étude des communautés végétales et de leur environnement, Ecologia Mediterranea XVI (1990) 403-414.

[6] Bottner $P$., La pédogénèse sur roches-mères calcaires dans une séquence bioclimatique méditerranéo-alpine du sud de la France, Ph.D. thesis, Université de Montpellier, Montpellier, 1971, $271 \mathrm{p}$.

[7] Cepeda-Pizarro J.G., Maldonado M.B., Vilches J.L., Rojas M.A., Pereira N.P., A litter- bag study of mite densities (Actinedida and Oribatida) in Atriplex litter and soil of a desert site in northern Chile, J. Arid Environ. 23 (1992) 177-188.

[8] Di Castri F., Vitali-Di Castri V., Soil fauna of Mediterraneanclimate regions, in: Di Castri F., Goodall D.W., Specht R.L. (Eds.), Mediterranean Type Shrublands, Elsevier Scientific Publishing Company, Amsterdam, 1981, pp. 445-478.

[9] Gallardo A., Merino J., Leaf decomposition in two Mediterranean ecosystems of southwest Spain: influence of substrate quality, Ecology 74 (1993) 152-161.

[10] Gisin H., Collembolenfauna Europas, Museum d'Histoire Naturelle, Genève, 1960, 312 p.

[11] Hågvar S., Collembola in Norwegian coniferous forest soils. I. Relations to plant communities and soil fertility. Pedobiologia 24 (1982) 255-296.

[12] Hågvar S., Collembola in Norwegian coniferous forest soils. III. Relations to soil chemistry, Pedobiologia 27 (1984) 331339.

[13] Ibrahima A., Joffre R., Gillon D., Changes in litter during the initial leaching phase: an experiment on the leaf litter of Mediterranean species, Soil Biol. Biochem. 27 (1995) 931-939.

[14] Legakis A., Community structure and species richness in the Mediterranean-type soil fauna, in: Arianoutsou M., Groves R.H. (Eds.), Plant-Animal Interactions in Mediterranean-Type Ecosystems, Kluwer Academic Publishers, Dordrecht, 1994, pp. 37-45.

[15] Lossaint P., Soil-vegetation relationships in Mediterranean ecosystems of southem France, in: di Castri F., Mooney H.A. (Eds.), Mediterranean type ecosystems: origin and structure, Springer-Verlag, Berlin Heidelberg New York, 1973, pp. 199210.

[16] Majer J.D., Greenslade P., Soil and litter invertebrates, in: Specht (Ed.), Mediterranean type ecosystems, a data source book, Kluwer Academic Publishers, Dordrecht, 1988, pp. 197 226.

[17] Mangenot F., Toutain F., Les litières, in: Besson P. (Ed.), Actualités d'écologie forestière, Gauthier-Villars Publishers, Paris, 1980, pp. 3-59. 
[18] McClaugherty C., Berg B., Cellulose, lignin and nitrogen concentrations as rate regulating factors in late stages of forest litter decomposition, Pedobiologia 30) (1987) 101-112.

[19] Poinsot N.. Recherches sur l'écologie et l'éthologie des Collemboles de Provence et de Camargue, Ph.D. thesis, Université de Provence. Marseille, 1971, 356 p.

120| Poinsot-Balaguer N.. Dynamique des communautés de Collemboles en milieu xérique méditerranéen. Pedobiologia 16 (1976) $1-17$.

121] Poinsot-Balaguer N., Stratégies adaptatives des arthropodes du sol en région méditerranéenne, in: Di Castri F. Floret Ch., Rambal S., Roy J. (Eds.), Time Scales and Water Stress, 5th International Conference on Mediterranean Ecosystems. International Union of Biological Sciences, Paris, 1988, pp. 511-5.39.

[22] Poinsot-Balaguer N.. Sadaka N., Distribution saisonnière et verticale d'une population d'Onychiurus zschokkei Handschin (Collembole) dans une litière d'une forêt de chêne vert (Quercus: ilex Linné) de la région méditerranéenne française. Ecologia Mediterranea XII (1986) 9-1.3.

12.3] Poinsot-Balaguer N., Tabone E., Étude d'un écosystème forestier méditerranéen. I. Composition et structure des peuplements microarthropodiens du sol dans une forêt mixte (Chênes verts. Quercus ilex L. - Chênes blancs, Quercus pubescens W.F.) de la région provençale, Bull. Ecol. I6 (1985) 149-160).

124| Poinsot-Balaguer N., Racon L., Sadaka N., Le Petit J., Effects of tannin compounds on two species of Collembola. Eur. J. Soil Biol. 29 (1993) 1.3-16.

125| Ponge J.F., Application de l'analyse factorielle des correspondances à l'étude des variations annuelles dans les populations de microarthropodes. Bull. Ecol. IV (1973) 319-327.

|26| Rapp M.. Élude expérimentale de la libération d'éléments minéraux lors de la décomposition de litières d'essences méditerranéennes. C.R. Acad. Sci. Paris 264 (1967) 797-80)

127| Sgardelis S.P.. Sarkar S.. Asikidis M.D., Cancela da Fonseca J.P.. Stamou G.P.. Phenological patterns of soil microarthropods from three climate regions. Eur. J. Soil Biol. 29 (1993) 49-57.

128| Stamou G.P., Asikidis M.D.. Argyropoulou M.D., Sgardelis S.P., Ecological time versus standard clock time: the asymmetry of phenologies and the life history strategies of some soil arthropods from Mediterranean ecosystems. Oikos 66 (1993) $27-35$. 